\title{
Longitudinal variation of wood quality in the five forest species from Caatinga
}

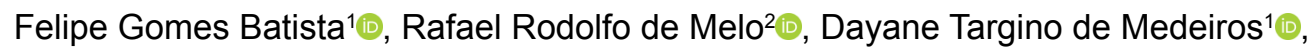
Antônio Giliard dos Santos Oliveira ${ }^{\circledR}{ }^{\circ}$, Cirilo Berson Alves Freitas ${ }^{2} \oplus$, Erick Daniel Gomes da Silva ${ }^{3}$, Alexandre Santos Pimenta ${ }^{1}{ }^{\circ}$

\footnotetext{
1 Universidade Federal do Rio Grande do Norte, Macaíba, Rio Grande do Norte, Brasil. E-mail: felipejp.gomes@gmail.com; dayanemedeirost@gmail.com; aspimenta@ufrnet.br

${ }^{2}$ Universidade Federal Rural do Semi-Árido, Mossoró, RN, Brasil. E-mail: rafael.melo@ufersa.edu.br; giliardsantosg545@gmail.com; ciriloberson@gmail.com

${ }^{3}$ Universidade Federal de Campina Grande, Patos, Paraiba, Brasil. E-mail: erickdufersa@gmail.com
}

ABSTRACT: The present study aimed to evaluate the dendrometric and chemical characteristics and variation of basic density and moisture content (green) of the wood of five Caatinga forest species along the commercial longitudinal direction (base-top) of logs. The studied species were pau-branco (Auxemma oncocalyx (Fr. All.) Taub.), jurema preta (Mimosa tenuiflora (Willd.) Poir.), jurema-de-embira (Mimosa ophthalmocentra Mart. ex Benth.), pereiro (Aspidosperma pyrifolium Mart.) and sabiá (Mimosa caesalpiniifolia Benth.). Fifteen trees were harvested, three of each species. The trees had diameter at breast height of 8 to $12 \mathrm{~cm}$. Five disks with thickness of $10 \mathrm{~cm}$ were removed from each tree at the positions 0 (base), 25, 50, 75 and $100 \%$ of the commercial height. The dendrometric characteristics showed that the choices of the trees contributed to a better analysis of the physicochemical properties of the wood. The five studied species could be described by the same model of longitudinal variation of basic density, decreasing from the base to top, while the moisture content (green) presented inverse behavior, with an increase in this same direction. All species had good quality for the production of sawn lumber, veneers, firewood and charcoal. In the chemical composition, the wood presented constituents that convey natural durability, as well as use for energy purposes.

\section{Variação longitudinal na qualidade da madeira de cinco espécies florestais da Caatinga}

RESUMO: O presente estudo teve como objetivo avaliar as características dendrométricas, químicas e a variação da massa específica básica e teor de umidade (verde), na madeira de cinco espécies florestais da Caatinga no sentido longitudinal (basetopo) do fuste comercial. As espécies estudadas foram pau branco (Auxemma oncocalyx (Fr. All.) Taub.), jurema preta (Mimosa tenuiflora (Willd.) Poir.), jurema-de-embira (Mimosa ophthalmocentra Mart. ex Benth.), pereiro (Aspidosperma pyrifolium Mart.) e sabiá (Mimosa caesalpiniifolia Benth.). Foram colhidas quinze árvores, três para cada espécie. As árvores apresentavam diâmetro à altura do peito de 8 a $12 \mathrm{~cm}$. De cada uma delas foram retirados cinco discos com $10 \mathrm{~cm}$ de espessura nas posições a 0 (base), 25, 50, 75 e 100\% da altura comercial do fuste. As características dendrométricas, evidenciaram que as escolhas das árvores, contribuíram para uma melhor análise das propriedades físico-químicas das madeiras. As cinco espécies estudadas apresentaram o mesmo modelo de variação longitudinal da massa específica básica, diminuindo da base para o topo, enquanto o teor de umidade (verde) teve comportamento inverso, com acréscimo nesse mesmo sentido. Todas as espécies apresentaram boa qualidade para produção de estacas, mourões, lenha e carvão. Na composição química, às madeiras apresentaram constituintes que influencia para uma melhor durabilidade natural, bem como para fins energéticos.

Palavras-chave: massa específica básica; propriedades físicas; variação base topo 


\section{Introduction}

The Caatinga biome, besides being unique to Brazil and covering wide genetic diversity of endemic animal and plant species, stands out in comparison with other semiarid regions of the world, due to its socio-environmental potential and ecological importance (Maia et al., 2017). The Caatinga flora provides resources that generate sustenance and income for families, including from timber species (firewood, charcoal, moors and sawn lumber) and non-timber species (fruits, seeds, fibers, oils and resins) (Silva et al., 2017).

In the case of timber species, wood varies greatly in its physical, mechanical, anatomical and chemical properties. Variations can even occur within the same individual, such as wood density, due to environmental, genetic and forestry factors during the tree growth (Modes et al., 2019).

According to Zaque et al. (2018), the density is the amount of woody matter per unit of volume, or conversely the volume of empty spaces present in a wood sample. This parameter is fundamental to determine the quality of wood for various uses, in addition to its correlation with other properties.

In addition to density, the moisture content also influences the strength of wood, since it is a hygroscopic material. That is, wood has the ability to retain and lose water. Moisture can also affect other properties, such as the density, retractability and mechanical, thermal and elastic properties (Araújo et al., 2016).

Knowledge of the physical properties of wood is fundamental, since these are associated with the various forms of industrial transformation. Density, for example, usually varies greatly in the longitudinal and radial direction of the tree trunk, and determines different types of uses and various ways to obtain products (Gallio et al., 2016).

There is a need for analysis to quantify and classify the properties of native tree species of the Caatinga biome, in order to efficiently estimate the total and commercial volume that can be extracted. This information is important to guide silvicultural decisions to increase the production and profitability of forests, so as to benefit the local population.

Based on the above, this study aimed to evaluate the dendrometric and chemical characteristics and variation of the basic density and moisture content (green) in the wood of five Caatinga forest species in the longitudinal (base-top) direction of the trunk.

\section{Material and Methods}

Studied species, sampling and dendrometric characteristics

The species studied were pau-branco (Auxemma oncocalyx All.), jurema preta (Mimosa tenuiflora (Willd.) Poiret), juremade-embira (Mimosa ophthalmocentra Mart. ex Benth), pereiro (Aspidosperma pyrifolium Mart.) and sabiá (Mimosa caesalpiniifolia Benth.), all obtained from Fazenda Ipê in the municipality of Governador Dix-Sept Rosado, Rio Grande do Norte, Brazil (latitude 530'02"S and longitude 3725'34”W).
Three trees of each species were harvested with a diameter at breast height (DBH) between 8 and $12 \mathrm{~cm}$, with maximum uniformity, free of bifurcation and apparent defects in the wood. From each tree, five discs with $10 \mathrm{~cm}$ thickness were removed at positions 0 (base), 25, 50, 75 and $100 \%$ of the commercial trunk height.

According to the Köppen classification, the climate in the region is of the BSw' $h^{\prime}$ type, characterized as a warm and semiarid climate. The average annual rainfall is $712.1 \mathrm{~mm}$, with the highest rainfall between February and May. The temperature fluctuates between 21 and $36 \stackrel{\circ}{ } \mathrm{C}$, and average annual relative humidity is $70 \%$, with an average solar incidence of 2,700 hours. The vegetation in the region is classified as Caatinga. The soils that predominate are Rendzina, with moderate clayey texture and high fertility, imperfect drainage and flat relief, with regular aptitudes for natural pasture; and Eutrophic Cambisol, with medium to low fertility, clayey texture, flat relief and well or moderately drained, according to the Institute of Sustainable Development and Environment of Rio Grande do Norte (IDEMA, 2008).

To obtain the dendrometric characteristics, the trees were measured for diameter at breast height (DBH) and diameter at ground level (DGL). The trees were felled and the total height (TH) and commercial trunk height (CTH) were measured. In addition, the heights and diameters of the discs with and without bark were measured, taken from five positions from the base to the top.

\section{Volume determination and chemical analysis of wood}

The trunks were divided into logs with standardized dimensions between 0.90 and $1.20 \mathrm{~m}$ in length. The data on diameters of the discs from base and top, with and without bark, and length of the log were used to determine the volume of each tree according to Smalian's formula, according to Finger (1992), because it is most commonly applied in native forests (Equation 1).

$$
\mathrm{VS}=0.00007854 \cdot \frac{\mathrm{D}^{2}+\mathrm{d}^{2}}{2} \cdot \mathrm{L}
$$

where: VS - log volume, in $\mathrm{m}^{3} ; \mathrm{D}^{2}$ - diameter of the log base, in $\mathrm{cm} ; \mathrm{d}^{2}$ - diameter of the top of the log, in $\mathrm{cm}$; L - log length, in $\mathrm{m}$.

The surplus samples (not used to determine the physical characteristics), obtained from the first section of the trees of each species, were used for chemical analyses following the methods described in the standards, T $207 \mathrm{~cm}-99$, Technical Association of the Pulp \& Paper Industry (TAPPI, 1999a), T $222 \mathrm{~cm}-88$ (TAPPI, 1999b) and Brazilian Technical Standard (NBR) 13999, from the Brazilian Association of Technical Standards (ABNT, 2003), to determine the levels of extractives in hot water, lignin and ash, respectively. All analyses were performed in triplicate for each species. The holocellulose content was estimated by the difference between the total chemical composition and the fractions of non-carbohydrates (Equation 2). 


$$
\text { Thol }=100-(\text { Text }+ \text { Tlig }+ \text { Tcz })
$$

where: Thol - Holocellulose (\%); Text - Extractives (\%); Tlig Lignin (\%); Tcz - Ash (\%).

\section{Determination of physical characteristics}

The discs of the sampled sections $(0,25,50,75$ and $100 \%$ of the commercial height) were used to determine the basic density, in which the value was obtained by the hydrostatic scale method (Vital, 1984), while the moisture content (green) was calculated in relation to the dry base. The weight was considered constant when the difference between two consecutive weighings performed 24 hours apart was less than $1 \%$. For this, the samples were dried in an oven at 103 $\pm 2{ }^{\circ} \mathrm{C}$ until reaching constant weight. The dry weight of the samples was determined with a scale with precision of $0.01 \mathrm{~g}$. In addition, the porosity of the wood samples was determined by the formula proposed by MacLean (1952), according to Equation 3.

$$
\mathrm{P}=1-\left(\frac{\mathrm{BD}}{\mathrm{BDcw}}\right) \cdot 100
$$

where: $\mathrm{P}$ - Porosity, in \%; BD - Basic density, in $\mathrm{g} \mathrm{cm}^{-3}$; BDcw Cell-wall density of wood, $1.54 \mathrm{~g} \mathrm{~cm}^{-3}$.

To determine the basic density of each tree, the method cited by Vital (1984) was used, in which the weighted average was used, when considering the volume between the sections from which the discs (samples) were taken as a weighting factor (Figure 1).

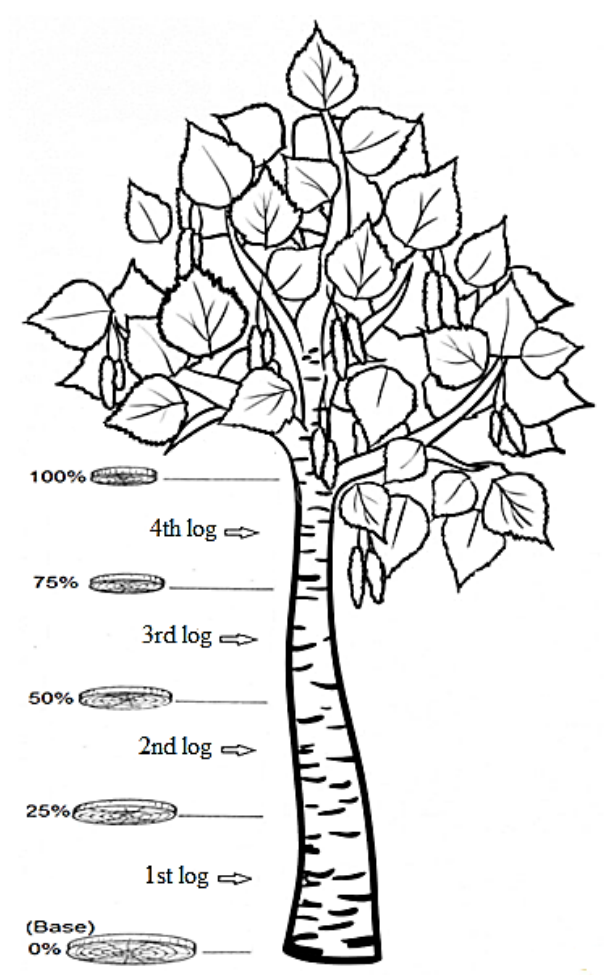

Figure 1. Sampling method for determining the mean basic density of the tree.
The arithmetic mean of basic density was calculated by summing all the mean values and dividing by the number of discs, while the mean weighted by volume was determined as cited by Vital (1984), by Equation 4.

$$
\mathrm{BDp}=\frac{[\mathrm{BDm}(0-25 \%) \cdot \mathrm{V}(0-25 \%)]+\ldots+[\mathrm{BDm}(75-100 \%) \cdot \mathrm{V}(75-100 \%)]}{\mathrm{V}(0-25 \%)+\mathrm{V}(5-50 \%)+\mathrm{V}(50-75 \%)+\mathrm{V}(75-100 \%)}
$$

where: BDp - Weighted average basic density of the tree, $\mathrm{g}$ $\mathrm{cm}^{-3}$; BDm - Average basic density between positions, $\mathrm{g} \mathrm{cm}^{-3}$; $\mathrm{V}$ - Volume of sections between positions $\left(\mathrm{m}^{3}\right)$.

To establish equations to estimate the basic wood density from the discs taken from each position of the trunk, the maximum moisture content method was used, as described by Smith (1954), in comparison with the equation obtained by the hydrostatic scale (water displacement).

\section{Statistical analysis}

A completely randomized design was used, consisting of five treatments (species) and three replicates (trees). A simple linear regression model was applied to evaluate the basic density and moisture content in the base-top direction of the trunk. Additionally, the same statistical modeling was applied to evaluate the method of determining the basic density of the wood obtained by the hydrostatic scale, estimated as a function of the maximum moisture content.

The data on arithmetic and weighted means of the basic density, porosity, dendrometric parameters and chemical composition of each species, after transformation and previous verification of statistical assumptions (normality, homoscedasticity and independence of the residuals), were submitted to analysis of variance (ANOVA), and when significant differences were found, the results were compared with each other by the Tukey test $(p<0.05)$.

\section{Results and Discussion}

\section{Dendrometric characteristics}

The dendrometric characteristics analyzed presented the highest mean values of total and commercial height for Mimosa tenuiflora and lowest for Mimosa ophthalmocentra (Table 1).

Regarding the volume with and without bark of the five species, the highest mean values were observed for Mimosa tenuiflora $\left(0.066 \mathrm{~m}^{3}\right)$ and Auxemma oncocalyx $\left(0.058 \mathrm{~m}^{3}\right)$, respectively, while the lowest values were for Mimosa caesalpiniifolia, with 0.048 and $0.0042 \mathrm{~m}^{3}$. The trees had $\mathrm{DBH}$ values ranging from 8 to $12 \mathrm{~cm}$ and were selected for maximum uniformity, without bifurcation and apparent wood defects.

\section{Density obtained by arithmetic and weighted means}

For the arithmetic and weighted mean values of the basic density of the wood, significant differences were observed between the five species (Table 2). Mimosa ophthalmocentra presented the highest basic density, of $\approx 916.70 \mathrm{~kg} \mathrm{~m}^{-3}$, 
Table 1. Mean values of dendrometric characteristics of the five timber species studied.

\begin{tabular}{lcccc}
\hline \multirow{2}{*}{ Specie } & \multicolumn{2}{c}{ Tree height $(\mathrm{m})$} & \multicolumn{2}{c}{ Tree volume $\left(\mathrm{m}^{\mathbf{3}}\right)$} \\
\cline { 2 - 5 } & Total & Commercial & With bark & Without bark \\
\hline Auxemma oncocalyx & $6.83 \pm 0.88$ & $4.36 \pm 0.37$ & $0.061 \pm 0.21$ & $0.058 \pm 0.19$ \\
Mimosa tenuiflora & $7.06 \pm 0.30$ & $4.80 \pm 0.75$ & $0.066 \pm 0.29$ & $0.053 \pm 0.22$ \\
Mimosa ophthalmocentra & $5.86 \pm 0.41$ & $3.58 \pm 0.55$ & $0.049 \pm 0.07$ & $0.045 \pm 0.06$ \\
Aspidosperma pyrifolium & $6.26 \pm 0.20$ & $4.53 \pm 0.23$ & $0.062 \pm 0.18$ & $0.052 \pm 0.14$ \\
Mimosa caesalpiniifolia & $6.63 \pm 0.65$ & $4.23 \pm 0.35$ & $0.048 \pm 0.05$ & $0.042 \pm 0.07$ \\
\hline
\end{tabular}

Table 2. Basic density obtained by arithmetic and weighted means, and porosity of the five timber species studied.

\begin{tabular}{|c|c|c|c|}
\hline \multirow{2}{*}{ Specie } & \multicolumn{2}{|c|}{ Basic density $\left(\mathrm{kg} \mathrm{m}^{-3}\right)$} & \multirow{2}{*}{ Porosity (\%) } \\
\hline & Arithmetic & Weighted & \\
\hline Auxemma oncocalyx & $769.84 \pm 25.79 b c$ & $775.90 \pm 35.91 b c$ & $48.68 \pm 1.72 \mathrm{ab}$ \\
\hline Mimosa tenuiflora & $822.69 \pm 24.87 a b$ & $841.80 \pm 33.95 a b$ & $45.15 \pm 1.66 b c$ \\
\hline Mimosa ophthalmocentra & $916.70 \pm 25.78 a$ & $921.46 \pm 19.77 \mathrm{a}$ & $38.89 \pm 1.72 \mathrm{c}$ \\
\hline Aspidosperma pyrifolium & $689.63 \pm 35.11 c$ & $704.37 \pm 34.19 c$ & $54.02 \pm 2.34 \mathrm{a}$ \\
\hline Mimosa caesalpiniifolia & $874.76 \pm 87.37 \mathrm{ab}$ & $878.48 \pm 82.00 \mathrm{ab}$ & $41.68 \pm 5.83 b c$ \\
\hline
\end{tabular}

Average \pm standard deviation. Averages followed by the same lower-case letter, in the same column, do not differ (Tukey, $\mathrm{p}>0,05)$.

followed by $M$. caesalpiniifolia and $M$. tenuiflora, which did not differ statistically, with values of 874.76 and $822.69 \mathrm{~kg}$ $\mathrm{m}^{-3}$, respectively. Aspidosperma pyrifolium $\left(689.63 \mathrm{~kg} \mathrm{~m}^{-3}\right)$ and Auxemma oncocalyx (769.84 $\mathrm{kg} \mathrm{m}^{-3}$ ) had lower results. In relation to weighted mean, the mean values of the five species had significant behavior similar to that of the arithmetic mean.

The values of mean basic density in this study were lower than those reported by Oliveira (2003) for Mimosa tenuiflora $\left(929.47 \mathrm{~kg} \mathrm{~m}^{-3}\right.$ ) and Aspidosperma pyrifolium (813.22 $\mathrm{kg} \mathrm{m}^{-3}$ ). According to Modes et al. (2019), the climatic and edaphic conditions of the growing site and their interaction with the genetics of the species are factors that can influence the variation of the basic density among individuals of the same species. This can explain the differences observed, since in the Caatinga biome there are heterogeneities of phytophysiognomies and rainfall irregularities in each microregion. An additional factor is the age of the trees sampled, which in both studies was not reported.

Mean values of basic density of $740.99 \mathrm{~kg} \mathrm{~m}^{-3}$ for Myracrodruon urundeuva and $601.96 \mathrm{~kg} \mathrm{~m}^{-3}$ for Leucaena leucocephala were obtained by Silva et al. (2017), while Almeida et al. (2015) obtained mean values of 1001.93 and $631.81 \mathrm{~kg} \mathrm{~m}^{-3}$, respectively, for Piptadenia stipulacea and Amburana cearenses. These differences can be attributed to variations of growing areas such as temperature, precipitation and soil conditions, in addition to tree age, all of which can directly influence the characteristics of the wood, such as basic density, as verified by Morais et al. (2017).
According to the Laboratory of Forest Products (LPF, 2017), the wood from species like Aspidosperma pyrifolium, with average basic density values between 500.00 and 720.00 $\mathrm{kg} \mathrm{m}^{-3}$, are classified as of medium density, while the other species studied were classified as having high density (> $720.00 \mathrm{~kg} \mathrm{~m}^{-3}$ ).

For porosity (Table 2), the wood of Aspidosperma pyrifolium and Auxemma oncocalyx had similar values. Mimosa ophthalmocentra exhibited the lowest value, but it did not differ significantly in relation to Mimosa tenuiflora and Mimosa caesalpiniifolia. This result may be associated with the wood density, because the higher the thickness of the cell wall, and consequently the amount of wood, the smaller the number of inter- and intracellular voids will be.

According to Gallio et al. (2016), the importance of this wood property depends on the intended use. Higher porosity can be disadvantage, since it increases the wood's capacity to exchange moisture with the environment until reaching equilibrium, decreasing the mechanical strength, and compromising on the quality of the material, due to the appearance of defects such as cracks and warping.

\section{Chemical characterization of wood}

The highest extractive contents were found for Mimosa tenuiflora and Mimosa caesalpiniifolia. The extractive values of these two species (Table 3) were also higher than those observed for Caesalpiniifolia pyramidalis (11.81\%) and Handroanthus impertiginosus (6.88\%) by Medeiros et

Table 3. Chemical composition of the five timber species studied.

\begin{tabular}{lcccc}
\hline \multirow{2}{*}{ Specie } & Extractive & Lignin & Ash & Holocellulose \\
\cline { 2 - 6 } & & & (\%) & \\
\hline Auxemma oncocalyx & $10.42 \pm 0.07 \mathrm{~b}$ & $30.34 \pm 6.32 \mathrm{a}$ & $4.84 \pm 0.50 \mathrm{a}$ & $54.4 \pm 13.41 \mathrm{a}$ \\
Mimosa tenuiflora & $14.62 \pm 0.05 \mathrm{a}$ & $31.77 \pm 9.40 \mathrm{a}$ & $0.90 \pm 0.16 \mathrm{C}$ & $52.71 \pm 15.47 \mathrm{a}$ \\
Mimosa ophthalmocentra & $8.96 \pm 0.12 \mathrm{~b}$ & $33.36 \pm 9.45 \mathrm{a}$ & $2.29 \pm 0.24 \mathrm{~b}$ & $55.39 \pm 16.36 \mathrm{a}$ \\
Aspidosperma pyrifolium & $10.91 \pm 0.02 \mathrm{~b}$ & $21.94 \pm 0.78 \mathrm{a}$ & $0.83 \pm 0.11 \mathrm{C}$ & $66.32 \pm 10.56 \mathrm{a}$ \\
Mimosa caesalpiniifolia & $14.92 \pm 0.12 \mathrm{a}$ & $32.10 \pm 3.01 \mathrm{a}$ & $3.11 \pm 0.50 \mathrm{~b}$ & $49.87 \pm 14.58 \mathrm{a}$ \\
\hline
\end{tabular}

Average \pm standard deviation. Averages followed by the same lower-case letter, in the same column, do not differ (Tukey, $p>0,05)$. 
al. (2012); Piptadenia stipulacea (13.17\%) by Almeida et al. (2015); and Myracrodruon urundeuva (12.5\%) and Leucaena leucocephala (10.80\%) by Silva et al. (2017).

According to Brénaud et al. (2011), these values indicate that the evaluated wood samples contain high levels of extractives, since the average amount in tropical wood is usually $7.6 \%$. According to Hassan et al. (2017), the composition and quantity of extractives varies between species and genera. Some of these substances have metabolic functions, while others ensure greater resistance of wood against fungi and xylophagous insects.

Lignin contents were similar among the species. According to Özparpucu et al. (2019), higher lignin content can imply greater degradation of carbohydrates and dissolution of low molecular weight polysaccharides, which causes a reduction in yield, pulp viscosity and physical resistance, besides generating a greater amount of solids to be burned in boilers. This fact can be observed when such quantities found for the studied timber species are compared. According to Mounguengui et al. (2016), lignin is important to increase the durability of wood, since it is a less hygroscopic component. It also has importance in the production of charcoal, by increasing yield.

Auxemma oncocalyx contained the highest amount of ash among the studied species, while the lowest values were for
Aspidosperma pyrifolium and Mimosa tenuiflora, with only 0.83 and $0.90 \%$, respectively. For two other species occurring in the Caatinga biome, Silva et al. (2017) obtained ash content below $1.08 \%$, and reported that a high amount of ash can result in equipment damage, in addition to the need for more frequent cleaning in wood combustion systems. Thus, the lower the ash content of wood, the better the desired characteristic will be, mainly for energy purposes and pulp and paper production (Silva et al., 2017).

The species exhibited similar amounts of holocellulose. The higher the holocellulose content in the wood, the lower the percentage of lignin will be, as well as the gravimetric yield of charcoal, since holocellulose degrades at temperatures between 200 and $350{ }^{\circ} \mathrm{C}$ and charcoal is produced with temperatures above $400{ }^{\circ} \mathrm{C}$. One of the factors that can influence the total value of holocellulose is the tree age, where younger trees have lower lignin content.

\section{Longitudinal variation of density}

In general, a good relationship was verified for the basic density and longitudinal position along the trunk for Mimosa tenuiflora and Aspidosperma pyrifolium, while Auxemma oncocalyx and Mimosa ophthalmoocentra presented moderate correlation coefficients (Figure 2). Only for Mimosa
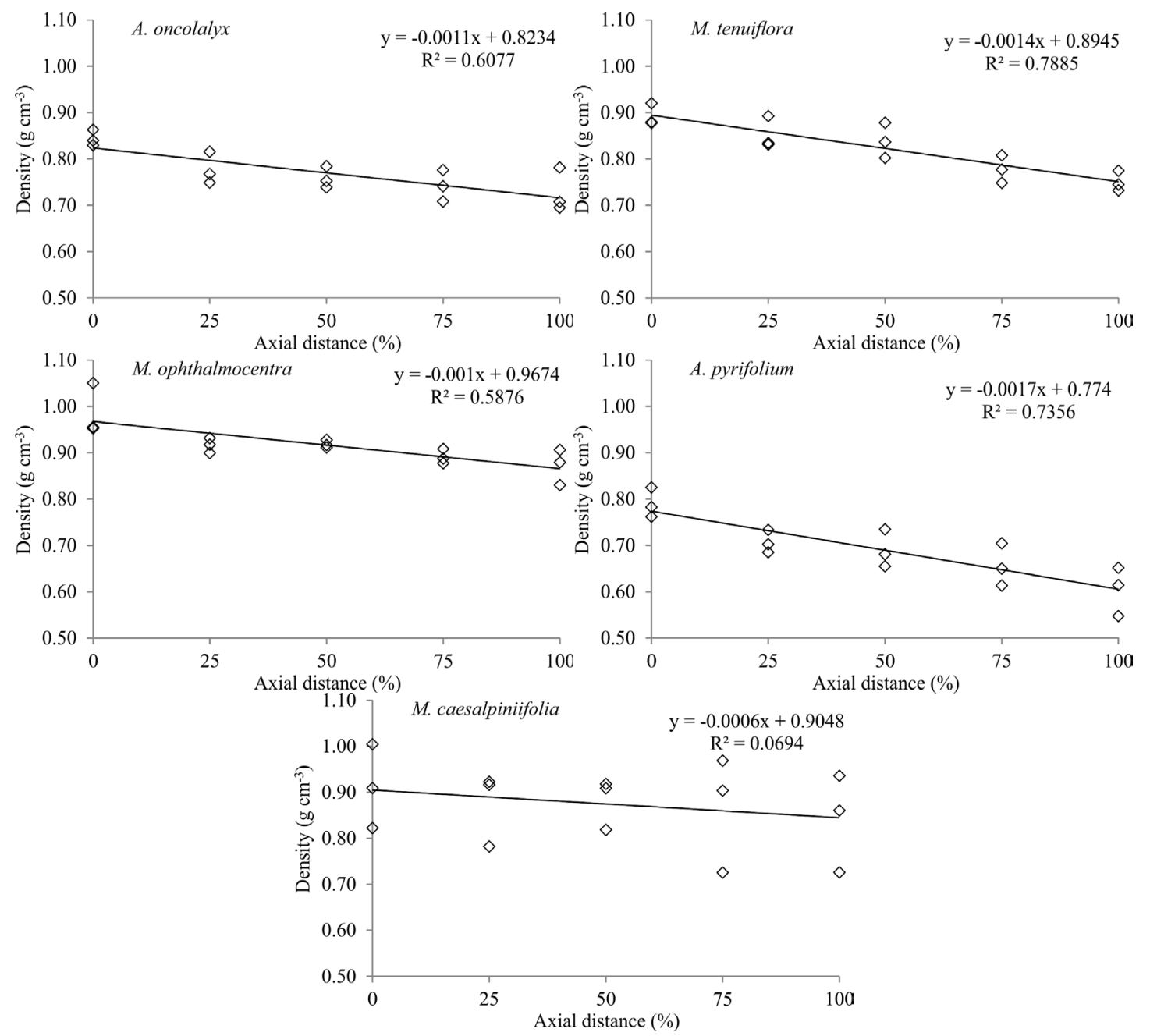

Figure 2. Variation of the basic density (BD) of the wood from the base-top trunk positions of the five timber species studied. 
caesalpiniifolia was no significant relationship identified between the variables studied.

There was a decrease in the basic density in the base-top direction of the tree. The density along the trunk is not uniform, because there are anatomical variations of its elements, a fact that also occurs in the radial direction (medulla-bark). The greater proportion of young wood as the height increases and the greater proportion of heartwood found at the base of the tree explain the decrease in density in the upper positions of the trunk. Zaque et al. (2018) stated that this alteration can also be caused by excessive competition, causing disuniformity of the wood along the trunk.

Regarding the basic density of Mimosa caesalpiniifoliana axial wood, Gonçalves et al. (2010) observed a decrease in the values in the base-top direction, a situation similar to that found in the present study for all species.

The basic density of wood is an essential property for evaluating the potential final use. Wood with high basic density (Mimosa tenuiflora, $M$. ophthalmoocentra, and M. caesalpiniifolia) tends to have greater resistance to deterioration caused by abiotic agents (sunlight, moisture and soil chemical compounds) and biotic agents (bacteria, fungi, insects and marine organisms). This characteristic is intrinsically associated with other factors that influence
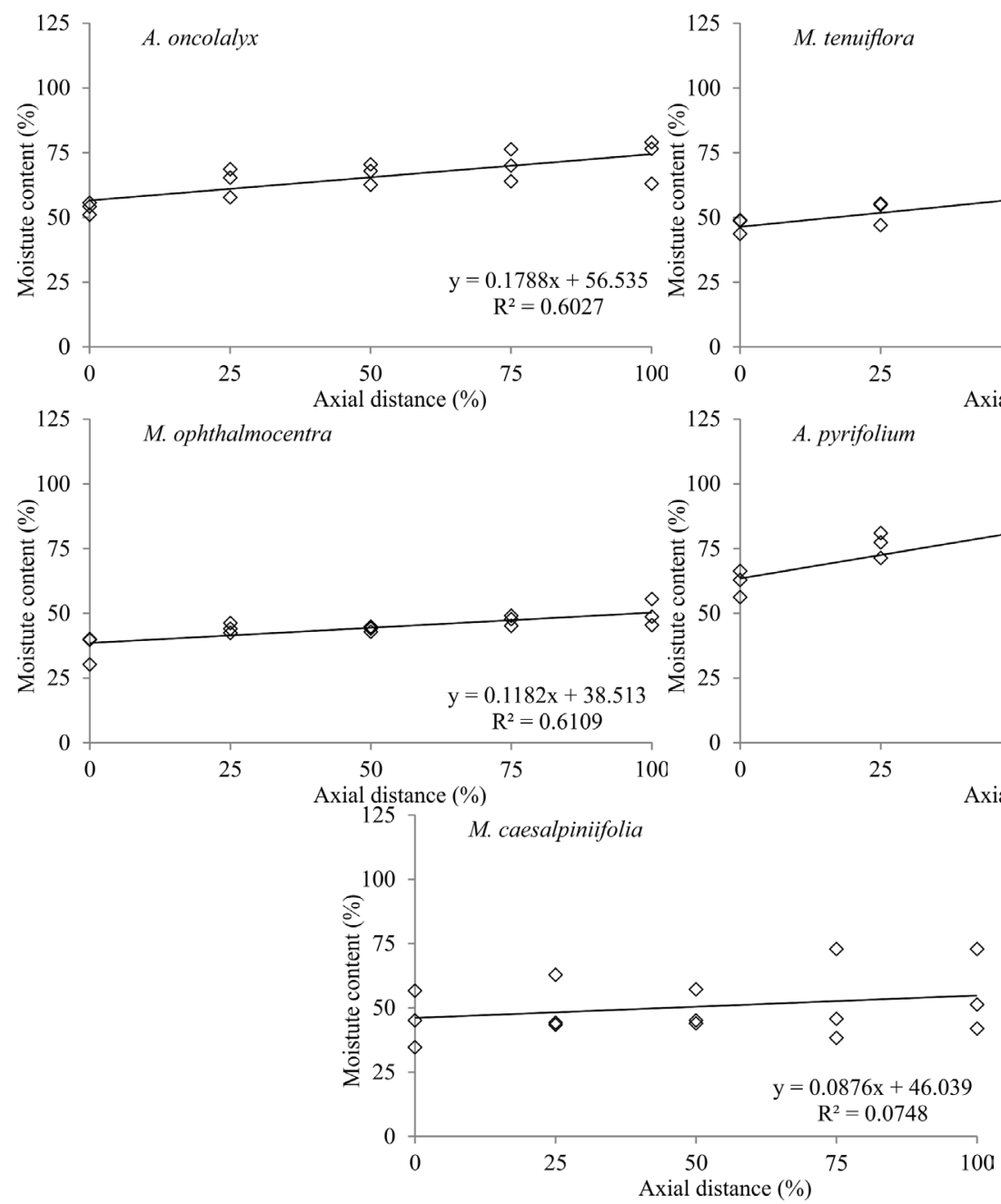

Figure 3. Variation of moisture content of wood from the base-top positions of the five timber species studied. natural resistance, such as the chemical composition of woody biomass (extractives) and the heartwood:sapwood ratio.

\section{Longitudinal variation of moisture content}

Regarding the moisture content (green) obtained from the wood samples along the base-top direction, the regression models had good fits for Mimosa tenuiflora and Aspidosperma pyrifolium, while Auxemma oncocalyx and Mimosa ophthalmoocentra presented moderate correlation coefficients (Figure 3). However, only for the species Mimosa caesalpiniifolia, was a significant relationship between the variables studied not identified.

There was an increase in the moisture content in the basetop direction, thus indicating the moisture content is inversely proportional to the density of the wood, due to the higher proportion of heartwood found in the lower part of the trunk and younger wood at the top. According to Costa et al. (2017), higher moisture content in the heartwood can hinder its drying, since it is less permeable than sapwood, mainly due to the obstruction of the vessels by tyloses and bud resins, caused by the cernification process, which makes it difficult to transport water from the inner to the outer parts of the wood.

For the mean values of moisture content, Aspidosperma pyrifolium (81.59\%) presented the highest value, followed
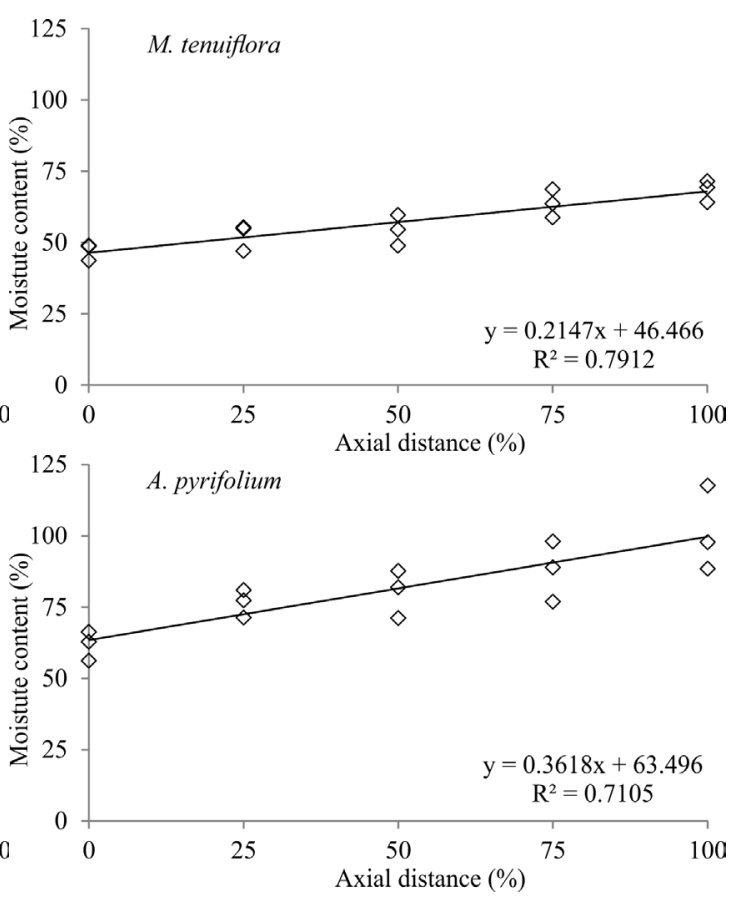
. 

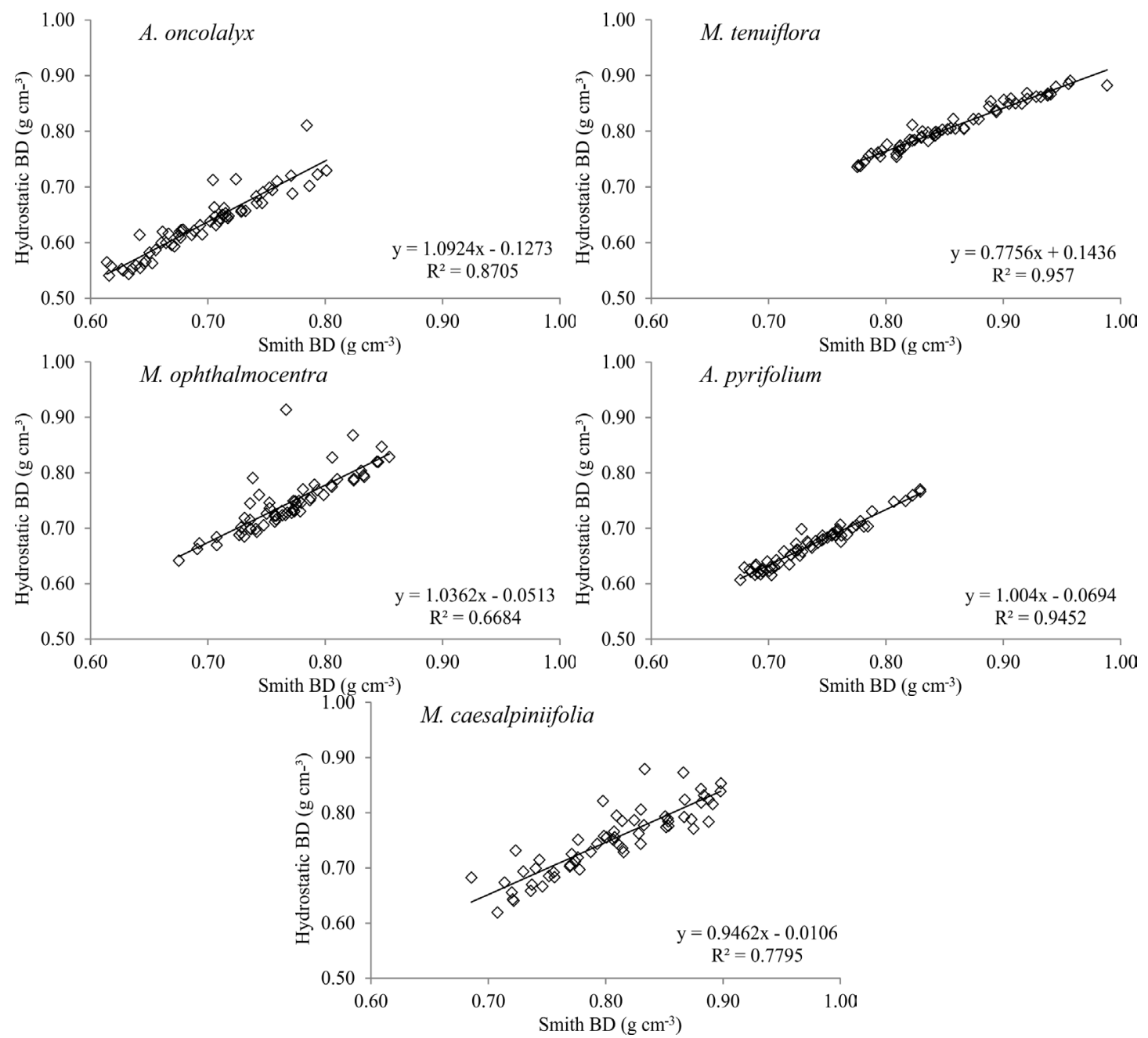

Figure 4. Values of the basic density (BD) obtained by the method of displacement in water and maximum moisture content (Smith) for the five timber species studied.

by Auxemma oncocalyx with $65.47 \%$, while Mimosa ophthalmoocentra presented the lowest moisture content, with $44.42 \%$. Mimosa caesalpiniifolia (50.42\%) and Mimosa tenuiflora $(57.20 \%)$ had intermediate mean values, higher than those reported by Gonçalves et al. (2010) and Rocha et al. (2015), respectively, for the same timber species.

For Cerrado timber species, Abrahão et al. (2020) found higher mean moisture content (green) values for Caryocar brasiliense than all the species of the present study, with $96.18 \%$. According to Zen et al. (2019), when moisture is lost or gained below the saturation point of the fibers, changes in the dimensions of items produced from wood begin to occur, so it is essential to measure the moisture, especially after drying and during storage, to avoid defects such as warping and cracking.

Figure 4 shows the comparisons between the methods of water displacement (hydrostatic scale) and maximum moisture content (Smith, 1954), in determining the basic density of the five timber species studied. These two methods presented good correlations for four of the five species studied, thus being efficient for validation of the basic density in the basetop direction, obviating the need to measure the volume of samples. The exception was Mimosa ophthalmocentra, in which there was a moderate correlation coefficient.
Thus, the maximum moisture content method applied in the present study, due to its ease of execution, can be used to determine the basic density on a large scale.

\section{Conclusions}

The dendrometric characteristics showed that the choice of the trees contributed to a better analysis of the physicochemical properties of the wood samples, even though the climatic and edaphic conditions of the growing site and their genetic interactions can present high alterations, caused by the heterogeneity of the trees.

In general, the five timber species studied presented the same model of longitudinal variation of the basic density, decreasing from base to top, while moisture content (green) increased in the same direction.

All species presented medium to high basic density, and can thus be used for the production of sawn lumber, veneers, firewood and charcoal. But care is required in drying and storage to avoid defects and attacks of xylophagous agents.

Based on the chemical composition, the wood of all species had high levels of extractives and lignin, which improve natural durability, while the ash content had desired 
levels for energy purposes, except for Auxemma oncocalyx, in which high values of this inorganic material were measured.

\section{Acknowledgements}

The Federal University of Rio Grande do Norte (UFRN) and Federal University of the Semi-Arid Region (UFERSA) provide a structure for the development of the study.

\section{Literature Cited}

Abrahão, C. P.; Campos, I. P. F.; Borges, C. C.; Cruz, T. M.; Mascarenhas, A. R. P.; Faria, C. T. E.; Duarte, P. J. Variação radial das propriedades da madeira de Caryocar brasiliense Cambess. (pequi-do-cerrado). Revista Ibero Americana de Ciências Ambientais, v. 11, n. 2, p. 14-22, 2020. https://doi.org/10.6008/CBPC2179-6858.2020.002.0002.

Almeida, A. M. C.; Oliveira, E.; Calegari, L.; Medeiros Neto, P. N.; Pimenta, A. S. Avaliação físico-química e energética da madeira das espécies Piptadenia stipulacea (Benth.) Ducke e Amburana cearensis (Allemão) AC Smith de ocorrência no semiárido nordestino brasileiro. Ciência Florestal, v. 25, n. 1, p. 165-173, 2015. https://doi.org/10.1590/1980-509820152505165.

Araújo, B. H. P.; Souza, M.; Nascimento, H. Propriedades físicas da madeira de Calycophyllum spruceanum Benth. em função do diâmetro e da posição (base e topo) no fuste. Scientia Forestalis, v. 44, n. 111, p. 759-768, 2016. https://doi.org/10.18671/scifor.v44n111.22.

Associação Brasileira de Normas Técnicas - ABNT. NBR 13999: Papel, cartão, pastas celulósicas e madeira - Determinação do resíduo (cinza) após a incineração a 525 C. ABNT: Rio de Janeiro, 2003.

Brémaud, I.; Amusant, H.; Minato, K.; Gril, J.; Thibaut, B. Effect of extractives on vibrational properties of African Padauk (Pterocarpus soyauxii Taub.). Wood Science and Technology, v. 45, n. 3, p. 461472, 2011. https://doi.org/10.1007/s00226-010-0337-3.

Costa, A. C. S.; Leal, C. S.; Santos, L. C.; Carvalho, A. M. M. L.; Oliveira, A. C.; Pereira, B. L. C. Propriedades da madeira de cerne e alburno de Eucalyptus camaldulensis. Revista Ciência da Madeira, v. 8, n. 1, p. 10-20, 2017. https://doi.org/10.15210/cmad.v8i1.8926.

Finger, C. A. G. Medição de Árvores. Fundamentos de biometria florestal. Santa Maria: Universidade Federal de Santa Maria; Centro de Pesquisas Florestais; Fundação de Apoio à Tecnologia e Ciência, 1992. 269 p.

Gallio, E.; Santini, E. J.; Gatto, D. A.; de Souza, J. T.; Ravasi, R.; Menezes, W. M.; Floss, P. A.; Beltrame, R. Caracterização tecnológica da madeira de Eucalyptus benthamii Maiden et Cambage. Revista Scientia Agraria Paranaensis, v. 15, n. 3, p. 244-250, 2016. https:// doi.org/10.1818/sap.v15i3.13557.

Gonçalves, C. A.; Lelis, R. C. C.; Heber, S. A. Caracterização físicoquímica da madeira de sabiá (Mimosa caesalpiniaefolia Benth.). Revista Caatinga, v. 23, n. 1, p. 54-62, 2010. https:// periodicos.ufersa.edu.br/index.php/caatinga/article/view/1348. 01 Apr. 2020.

Hassan, B.; Mankowski, M. E.; Kirker, G.; Ahmed, S. Effects of heartwood extractives on symbiotic protozoan communities and mortality in two termite species. International Biodeterioration \& Biodegradation, v. 123, p. 27-36, 2017. https://doi.org/10.1016/j. ibiod.2017.05.023.
Instituto de Desenvolvimento Sustentável e Meio Ambiente do Rio Grande do Norte - IDEMA. Perfil do seu município: Governador Dix Sept Rosado. v.10. Natal: IDEMA, 2008. 23p. http://adcon. rn.gov.br/ACERVO/idema/DOC/DOC000000000015024.PDF. 02 Jul. 2020.

Laboratório de Produtos Florestais - LPF. Ministério da Agricultura, Pecuária e Abastecimento. Serviço Florestal Brasileiro. Database of brazilian woods. Brasília: SBF, 2017. http://sistemas.florestal. gov.br/madeirasdobrasil. 02 Jul. 2020.

Maclean, J. D. Preservative treatment of wood by pressure methods. Madison: U. S. Department of Agriculture; Forest Service; Forest Products Laboratory, 1952. 160 p. (USDA. Agriculture Handbook, 40). https://www.fpl.fs.fed.us/documnts/usda/ah40.pdf. 22 Jun. 2020.

Maia, J. M.; Sousa, V. F. O.; Lira, E. H. A.; Lucena, A. M. A. Motivações socioeconômicas para a conservação e exploração sustentável do bioma Caatinga. Desenvolvimento e Meio Ambiente, v. 41, p. 295-310, 2017. https://doi.org/10.5380/dma.v41i0.49254.

Medeiros Neto, P. N.; Oliveira, E.; Calegari, L.; Almeida, A. M. C.; Pimenta, A. S.; Carneiro, A. C. O. Características físico-químicas e energéticas de duas espécies de ocorrência no semiárido brasileiro. Ciência Florestal, v. 22, n. 3, p. 579-588, 2012. https:// doi.org/10.5902/198050986624.

Modes, K. S.; Ludwig, R. L.; Vivian, M. A.; Stolberg, J. Wood quality of Pinus patula Schltdl. \& Cham. for the pulp production. Revista Árvore, v. 43, n. 2, e430207, 2019. https://doi.org/10.1590/180690882019000200007.

Morais, P. H. D. D.; Longue Júnior, D.; Colodette, J. L.; Morais, E. H. D. C.; Jardim, C. M. Influence of clone harvesting age of Eucalyptus Grandis and hybrids of Eucalyptus grandis x Eucalyptus urophylla in the wood chemical composition and in kraft pulpability. Ciência Florestal, v. 27, n. 1, p. 237-248, 2017. https://doi. org/10.5902/1980509826462.

Mounguengui, S.; Tchinda, J. B. S.; Ndikontar, M. K.; Dumarçay, S.; Attéké, C.; Perrin, D.; Gelhaye, E.; Gérardin, P. Total phenolic and lignin contents, phytochemical screening, antioxidant and fungal inhibition properties of the heartwood extractives of ten Congo Basin tree species. Annals of Forest Science, v. 73, n. 2, p. 287 296, 2016. https://doi.org/10.1007/s13595-015-0514-5.

Oliveira, E. Características anatômicas, químicas e térmicas da madeira de três espécies de maior ocorrência no semiárido nordestino. Viçosa: Universidade Federal de Viçosa, 2003. 116 p. Tese Doutorado. https://www.locus.ufv.br/ bitstream/handle/123456789/9235/texto\%20completo. pdf?sequence=1\&isAllowed=y. 09 Apr. 2020.

Özparpucu, M.; Gierlinger, N.; Cesarino, I.; Burgert, I.; Boerjan, W.; Rüggeberg, M. Significant influence of lignin on axial elastic modulus of poplar wood at low microfibril angles under wet conditions. Journal of Experimental Botany, v. 70, n. 15, p. 40394047, 2019. https://doi.org/10.1093/jxb/erz180.

Rocha, H. L. S.; Paes, J. B.; Miná, A. J. S.; Oliveira, E. Caracterização físico mecânica da madeira de jurema-preta (Mimosa tenuiflora) visando seu emprego na indústria moveleira. Revista Brasileira de Ciências Agrárias, v. 10, n. 2, p. 262-267, 2015. https://doi. org/doi:10.5039/agraria.v10i2a3772. 
Silva, L. L. H.; Oliveira, E.; Calegari, L.; Pimenta, M. C.; Dantas, M. K. L. Características dendrométricas, físicas e químicas da Myracrodruon urundeuva e da Leucaena leucocephala. Floresta e Ambiente, v. 24, e20160022, 2017. https://doi.org/10.1590/21798087.002216 .

Smith, D.M. Maximum moisture content method for determining specific gravity of small wood samples. Madison: U.S. Department of Agriculture; Forest Service; Forest Products Laboratory, 1954. 8 p. (USDA. Forest Service, Report, 2014). https://www.fpl.fs.fed. us/documnts/fplr/fplr2014.pdf. 01 Apr. 2020.

Technical Association of pulp and Paper Industry - TAPPI. Tappi test method T $207 \mathrm{~cm}-99$. Water solubility of wood and pulp. Atlanta: Tappi Press, 1999a.
Technical Association of pulp and Paper Industry - TAPPI. Tappi test method T 222 om-88. Acid-insoluble lignin in wood and pulp. Atlanta: Tappi Press, 1999b.

Vital, B. R. Métodos de determinação da densidade da madeira. Viçosa: Sociedade de Investigações Florestais, 1984. 21 p. (SIF. Boletim Técnico, 1).

Zaque, L. A. M.; Ferreira, M. D.; Melo, R. R. Variação radial e longitudinal da massa específica básica da madeira de Araucaria angustifolia com diferentes idades. Pesquisa Florestal Brasileira, v. 38, n. 1, p. 1-5, 2018. https://doi.org/10.4336/2018.pfb.38e201601368.

Zen, L. R.; Monteiro, T. C.; Schaeffer, W.; Kaminski, J. M.; Klitzke, R. J. Secagem ao ar livre da madeira serrada de eucalipto. Journal of Biotechnology and Biodiversity, v. 7, n. 2, p. 291-298, 2019. https://doi.org/10.20873/jbb.uft.cemaf.v7n2.zen. 